\title{
FACTORS INFLUENCING PARTICIPATION IN HOMESTEAD CATFISH PRODUCTION IN DELTA STATE, NIGERIA
}

\author{
Odjuvwuederhie Emmanuel INONI ${ }^{1,2}$, Patterson Adogbeji EKOKOTU ${ }^{3}$, David Eduvie IDOGE ${ }^{4}$
}

Received Avgust 2, 2016; accepted September 25, 2017. Delo je prispelo 2. avgusta 2016, sprejeto 25. septembra 2017.

\begin{abstract}
Factors influencing participation in homestead catfish production in Delta State, Nigeria

Domestic fish production in Nigeria has been growing for the past decade, yet a widening demand-supply gap has persisted leading to a substantial loss in Nigeria's foreign exchange earnings due to fish imports. In order to boost household food fish supply many individuals have converted available land space within their homestead for catfish production. This study, therefore, investigated the effects of socio-economic variables on the participation in homestead catfish production in the Central Agricultural Zone of Delta State, Nigeria. Using data from 137 respondents engaged in catfish farming, the findings showed a mean age of 44 years for catfish farmers and an average land size of $104.35 \mathrm{~m}^{2}$ for pond construction. The probit model had a good fit with a Psuedo- $R^{2}$ of $0.62,90.5 \%$ of cases correctly predicted, and a significant likelihood ratio (LR) test $(p<0.01)$. Results of the probit analysis indicated that pond location, age, land area, adults per household, years of education, disposable income, and access to credit exerted a positive and significant effect on homestead catfish production participation decision.
\end{abstract}

Key words: aquaculture; fish; catfish production; economics; participation decision; Nigeria

\section{INTRODUCTION}

The global fish supply from capture fisheries and aquaculture was put at 158 million tonnes in 2012, with 136.2 million tonnes used for human consumption and providing an estimated apparent food fish per capita supply of about $19.2 \mathrm{~kg}$ (live weight equivalent). The con-

\section{Dejavniki odločanja o vključitvi $v$ domačo prirejo somov $v$ ni- gerijski pokrajini Delta State}

V Nigeriji je domača prireja rib v preteklem desetletju sicer naraščala, vendar je vse večji razkorak med povpraševanjem in ponudbo in posledično uvoz rib povzročil pomembno poslabšanje zunanjetrgovinske bilance Nigerije. Da bi izboljšali oskrbo gospodinjstev $\mathrm{z}$ ribami, so številni posamezniki začeli uporabljati razpoložljive površine znotraj svojih gospodarstev za prirejo somov. Študija proučuje učinke socio-ekonomskih dejavnikov na udeležbo pri domači prireji somov v osrednji kmetijski regiji Delta State v Nigeriji. Z uporabo podatkov 137 anketirancev, ki se ukvarjajo s prirejo soma, smo ugotovili povprečno starost rejcev 44 let in povprečno velikost zemljišča $104,35 \mathrm{~m}^{2}$, ki so jo namenil gradnji ribnika. Probit model se je dobro prilegal podatkom, kar kaže Psuedo- $R^{2}$ 0,62, 90,5 \% primerov smo pravilno napovedali, statistično značilen pa je bil tudi preizkus razmerja verjetja (LR) $(p<0,01)$. Rezultati probithe analize so pokazali, da imajo lokacija ribnika, starost lastni$\mathrm{ka}$, površina zemlje, število odraslih v gospodinjstvu, trajanje formalnega izobraževanja, razpoložljivi dohodek in dostop do kredita pozitiven in pomemben učinek na odločitev o sodelovanju pri prireji somov.

Ključne besede: akvakultura; ribogojstvo; ribe; somi; ekonomika; participativno odločanje; Nigerija

tribution of aquaculture to world fish supply reached an all-time level of 66.6 million tonnes in 2012 representing $42.2 \%$ of global fish production, while the values were 1,485,367 and 454,691 tonnes, respectively, for Africa and sub-Saharan Africa (FAO, 2014b). Aquaculture has continued to remain a growing, vibrant and important production sector for high protein food supply for hu-

\footnotetext{
Delta State University, Department of Agricultural Economics \& Extension, Abraka, Asaba, Delta State, Nigeria

2 Corresponding author, e-mail: inoniemma@gmail.com

3 Delta State University, Faculty of Agriculture, Department of Fisheries, Abraka, Asaba, Delta State, Nigeria

4 Same address as 1
} 
Table 1: Fish production, import and export bill in Nigeria

\begin{tabular}{|c|c|c|c|c|c|c|c|}
\hline Year & $\begin{array}{l}\text { Total fish } \\
\text { production } \\
\text { (tonnes) }\end{array}$ & $\begin{array}{l}\text { Capture } \\
\text { fisheries } \\
\text { (tonnes) }\end{array}$ & $\begin{array}{l}\text { Aquaculture } \\
\text { (tonnes) }\end{array}$ & $\begin{array}{l}\text { Catfish } \\
\text { (tonnes) }\end{array}$ & $\begin{array}{l}\text { Imports } \\
\text { (US\$ '000) }\end{array}$ & $\begin{array}{l}\text { Exports } \\
\text { (US\$ ‘000) }\end{array}$ & $\begin{array}{l}\text { Net Fish } \\
\text { Exports } \\
\text { (US\$ ‘000) }\end{array}$ \\
\hline 2000 & 467095 & 441,377 & 25,718 & 4,067 & 246,850 & 1,572 & $-245,278$ \\
\hline 2001 & 476544 & 452,146 & 24,398 & 4,387 & 452,770 & 13,786 & $-438,984$ \\
\hline 2002 & 511719 & 481,056 & 30,663 & 7,134 & 359,997 & 16,979 & $-343,018$ \\
\hline 2003 & 505839 & 475,162 & 30,677 & 10,015 & 484,423 & 17,733 & $-466,690$ \\
\hline 2004 & 509201 & 465,251 & 43,950 & 26,750 & 396,535 & 29,891 & $-366,644$ \\
\hline 2005 & 579537 & 523,182 & 56,355 & 34,582 & 613,497 & 56,827 & $-375,676$ \\
\hline 2006 & 636901 & 552,323 & 84,578 & 51,916 & 766,089 & 53,755 & $-400,493$ \\
\hline 2007 & 615507 & 530,420 & 85,087 & 52,229 & 892,771 & 50,126 & $-842,645$ \\
\hline 2008 & 744575 & 601,368 & 143,207 & 36,330 & 618,062 & 75,106 & $-542,956$ \\
\hline 2009 & 751006 & 598,210 & 152,796 & 75,662 & 786,075 & 146,931 & $-639,144$ \\
\hline 2010 & 817516 & 616,981 & 200,535 & 115,421 & 973,724 & 154,608 & $-819,116$ \\
\hline 2011 & 856614 & 635,486 & 221,128 & 122,681 & $2.027,797$ & 83,824 & $-194,3973$ \\
\hline 2012 & 922652 & 668,754 & 253,898 & 125,762 & $1.472,258$ & 331,052 & $-114,1206$ \\
\hline
\end{tabular}

Source: FAO, Yearbook of Fisheries and Aquaculture Statistics (2006, 2008, 2012, 2016); FAO, State of World Fisheries and Aquaculture, 2014.

man consumption in developing countries. Besides, it is a veritable source of income and employment for over 298,000 fish farmers, and many more people engaged in fish processing and marketing in Africa (FAO, 2014a).

Although domestic fish production has been growing in Nigeria since 2005, fish supply has continually fallen short of demand due to the rapidly growing human population. The situation has caused a widening demand-supply gap which has led to huge import of fish to augment local demand. Nigeria's fish import grew from 246,850 tonnes in 2000 to $2,027,797$ tonnes in 2011, culminating in an annual average fish import of 738,308.69 tonnes between 2000 and 2012 (FAO, 2014b). The nation's fish import bill gulped a whopping 2.03 billion US dollars in 2011, making Nigeria one of the largest importers of fish in the developing world (FAO, 2016).

Aquaculture, the farming of aquatic organisms including fish, molluscs, crustaceans and aquatic plants, is often cited as one of the means of efficiently increasing fish production in low-income, food-deficient countries. Aquaculture production has experienced a steady growth in Nigeria since the year 2000. With an output level of 24,398 metric tonnes in 2001, production reached a level of 253,898 metric tonnes in the year 2012 (Table 1). The Food and Agriculture Organisation (FAO) estimates revealed that different species of catfish such as Clarias gariepinus, Clarias species and Clarias-Heterobranchus hybrid appeared to be the predominant cultured fish species in Nigeria, as they accounted for $75.5 \%$ of total aquaculture production in the year 2014 (FAO, 2016).
The preference of farmers to culture catfish may be due to their better growth performance and survival (Adeogun et. al., 2008), as well as a better market value that is two to three times that of tilapia (Olagunju et. al., 2007). The level of aquaculture production appears to be rather low, given the declining yield of natural fish stocks due to over-exploitation and climate change, a situation that has resulted in huge import bills for fish. Given the present scenario, fish farming, and especially catfish farming still holds the greatest potential to rapidly boost domestic fish production and lead the nation towards self-sufficiency in fish production (Ugwumba, 2005; Inoni, 2007). Nigeria's potentials in fish farming were revealed by Welcome (1979), Tobor (1990) and Kapetsky (1981) who reported that putting $25 \%$ of swamplands, floodplains, and coastal lagoons in cultivation would yield over 717,470 tonnes of fish per year.

Fish farming is a major component of the agricultural production system in Delta State because of the abundant land and water resources that can support the cultivation of both marine and freshwater fish species. The prevailing hydrographic conditions have thus made fish farming a thriving agribusiness investment for smallholder fish farmers in the State. Furthermore, the adoption and diffusion of the innovation of catfish production in concrete tanks during the past six years have opened up new opportunities for resource-poor farmers to earn additional income, increase fish protein intake and enhance food security of their households. Nevertheless, the low quality fish seeds, high cost of feeds, lack of fish- 
ery extension services, low capital investment and inadequate technical knowledge on the part of farmers, have constrained the contribution of aquaculture to increased fish supply in Delta State (Inoni, 2007).

Although a number of research studies have been undertaken on the economics, efficiency, and profitability of fish farming in Delta State, not many have focused on factors that determine the participation in fish farming, and particularly catfish production, at home. Therefore, the major objective of this study was to determine factors that affect the participation in homestead catfish farming in the Central Agricultural Zone of Delta State, Nigeria. The specific objectives were to describe the socio-economic characteristics of homestead catfish producers, as well as to examine factors that influence the decision to participate in homestead catfish farming.

\section{MATERIALS AND METHODS}

\subsection{AREA OF STUDY AND SAMPLING PROCE- DURE}

The Central Agricultural Zone of Delta State comprising ten local government areas (LGAs); Udu, Uvwie, Okpe, Isoko North, Isoko South, Sapele, Ethiope West, Ethiope East, Ughelli North and Ughelli South was the location of study. Multi-stage sampling procedure was used to draw samples for the study. Firstly, seven LGAs (Isoko North, Isoko South, Ughelli North, Ethiope West, Uvwie, Ethiope East, and Ughelli South) were selected out of the ten LGAs that comprised the area of study, using a simple random sampling technique. In the second stage, twenty four respondents were drawn from each of the seven LGAs chosen to give a total sample size of 168 respondents. Primary data for the study were obtained from a cross-section of homestead catfish farmers and non-fish farmers using a structured questionnaire. Lists of fish farmers obtained from the Fisheries Department of the Delta State Ministry of Agriculture and Natural Resources (Asaba) and dealers of fish feeds and feed ingredients, constituted the sampling frame from which catfish producers were drawn. But due to non-response and inadequate information, thirty-one copies of the questionnaire were discarded, and data from 137 respondents were used for the analysis.

Data collected included socio-economic characteristics of respondents such as income level, level of inputs used, inputs cost, output of fish produced, fish sales, farm size, length of production period, quantity of home consumption, as well as labour utilisation. The survey was conducted between January 12 and March 19, 2016.

\subsection{PROBIT MODEL OF PARTICIPATION IN CAT- FISH PRODUCTION}

A farmer's decision to participate in homestead catfish farming can be expressed as a dichotomous binary variable based on whether the individual invests in fish farming or not. The model assumes that operators' decisions are based on utility maximisation, and that the individual decision to participate or not in fish production depends on an unobservable utility index or a latent variable that is determined by the farm and farmer specific characteristics (Damisa et. al., 2007; Chukwuji, 2010). The choice of the probit model for this study was quite appropriate because the error term is assumed to have normal distribution (Gujarati and Porter, 2009). Therefore, the probit model of participation in catfish farming is derived from an underlying latent variable model expressed as:

$Y_{\mathrm{i}}^{*}=\beta_{0}+\beta_{\mathrm{ij}} X_{\mathrm{ij}}+e_{\mathrm{i}}$

where $Y_{i}^{*}$ is an unobserved index reflecting the difference between the utility of participating or not participating in homestead fish production, $\beta_{0}$ is the intercept, $\beta_{\mathrm{ij}}$ is a vector of unknown parameters to be estimated; $X_{\mathrm{ij}}$ is a vector of operator's farm, location and socioeconomic characteristics, which are the independent variables that explain participation in fish farming, and $e_{\mathrm{i}}$ is the standard normally distributed error term that is independent of $X_{j}$ and is symmetrically distributed around zero (Wooldridge, 2006; Green, 2008). Following from equation (1), the model to estimate the probability of a farmer participating in catfish production can be stated as:

$\boldsymbol{P}\left(\boldsymbol{Y}_{\mathrm{i}}^{*}=1 \mid \boldsymbol{x}\right)=\boldsymbol{F}(\boldsymbol{\beta} \boldsymbol{X})=\int_{-\infty}^{\beta X} \frac{1}{\sqrt{2 \pi}} \exp \left(-z^{2} / 2\right) d z$

where $\mathrm{F}$ is the standard normal cumulative distribution function that ensures that the likelihood of participating in catfish farming lies strictly between zero and one, and $P$ is the probability that a farmer participates in catfish farming or not. Thus, $Y_{i}=1$ if $Y_{i}^{\star}>0 ; Y_{i}=0$ if $Y_{\mathrm{i}}^{*} \leq 0 ; Z=$ the standard normal variable (Gujarati and Porter, 2009). Following on from the foregoing discussion, the empirical model for quantifying the factors which influence the participation in homestead catfish production is explicitly specified as follows:

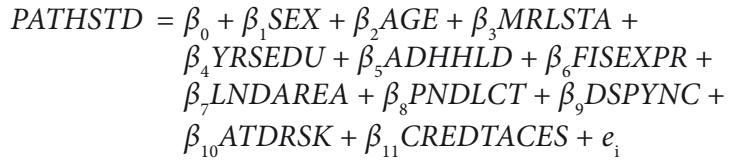


Table 2: Description and summary statistics of variables used in the probit model (Participation: dependent variable)

\begin{tabular}{|c|c|c|c|c|c|}
\hline Variable & Variable description & $\begin{array}{l}\text { Mean } \\
\text { (Mode) }\end{array}$ & $\begin{array}{l}\text { Std. } \\
\text { Deviation }\end{array}$ & Minimum & Maximum \\
\hline PATHSTD & 1 if participate in homestead catfish farming, 0 otherwise & 0.49 & 0.50 & 0.00 & 1.00 \\
\hline GENDER & Gender of catfish farmer ( 1 if male, 0 otherwise) & $(1.00)$ & 0.49 & 0.00 & 1.00 \\
\hline AGE & Age of fish farmer (years) & 43.77 & 9.85 & 26.00 & 63.00 \\
\hline MRLSTA & Marital status( 1 if married, 0 if single) & $(1.00)$ & 0.47 & 0.00 & 1.00 \\
\hline YRSEDU & Years of formal education & 9.92 & 4.55 & 0.00 & 17.00 \\
\hline ADHHLD & Number of adults in farmer's household & 2.85 & 0.83 & 2.00 & 5.00 \\
\hline FISEXPR & Fish farming experience (years) & 4.26 & 2.29 & 1 & 10.00 \\
\hline LNDAREA & Land area for pond construction $\left(\mathrm{m}^{2}\right)$ & 104.35 & 31.43 & 40.73 & 191.61 \\
\hline PNDLCTN & Pond location ( 1 if located in urban/surb-urban area, 0 if rural) & $(1.00)$ & 0.50 & 0.00 & 1.00 \\
\hline DSPYNC & Disposable income ( & $43,192.88$ & $18,274.85$ & $14,376.80$ & $84,031.68$ \\
\hline ATDRSK & Attitude to risk ( 1 if a risk taker, 0 otherwise) & $(0.00)$ & 0.53 & 0.00 & 1.00 \\
\hline CREDTACES & 1 for access to credit, 0 , otherwise & $(1.00)$ & 0.49 & 0.00 & 1.00 \\
\hline
\end{tabular}

Source: Computed from survey data, 2016

where the descriptions of the variables that affect the individual participation decision in homestead catfish production are as shown in Table 2. The parameter estimates were obtained by maximum likelihood estimation (MLE) procedure using LIMDEP 7.0 econometric software (Greene, 1998).

\section{RESULTS AND DISCUSSION}

\subsection{SOCIO-ECONOMIC CHARACTERISTICS OF HOMESTEAD CATFISH FARMERS}

The socio-economic characteristics of fish farmers (Table 3) revealed that although both men and women were actively involved in catfish farming in the study area, but men were predominant. A number of sociocultural factors limit the access of women to productive resources, external inputs and information (Doss and Morris, 2001). This may have resulted in a fewer number of women involved in catfish farming within the vicinity of the home.

The age of fish farmers ranged between 26 to 63 years with a mean age of 44 years. In fact, the majority of them $(92 \%)$ were within the acting labour force. The effect of age comes from accumulated knowledge and experience (Tenge et al., 2004). Furthermore, older farmers might have more personal capital from a long accumulation (Nkamleu and Manyong, 2005) and thus were more likely to invest in new technologies and participate in fish production around home.

The number of adults per farmer's household ranged from 2 to 5 , and this is related to the role family members' play as a source of labour in fish farming activities, which require a great deal of human effort from stocking, routine management to harvesting. Thus, households with an increased labour supply are more likely to adopt and participate in new technologies than those with fewer adults (Nkamleu and Manyong, 2005; Amsalu and de Graaff, 2007).

Over $90 \%$ of the farmers in the study acquired some level of formal education, but secondary education was the modal educational status attained. Education helps to create a favourable mental attitude for the acceptance of innovations and particularly of management-intensive practices such as catfish production (Caswell et al., 2001). Furthermore, apart from being early innovators that provide examples that may be copied by illiterate farmers and late adopters, educated farmers are more able to copy those who adopt innovation first, thereby enhancing the diffusion of the new technology in the community (Samiee et. al., 2007).

Land area available for pond construction is a very cardinal factor for the involvement in homestead catfish farming. Land area for pond construction ranged between 40.73 and $191.61 \mathrm{~m}^{2}$, with an average of $104.35 \mathrm{~m}^{2}$. Thus a number of potential investors in homestead fish farming are unable to do so because they do not have control over the land that is around their home. According to Doss and Morris (2001) farm size is the first and probably the most important determinant of participation. This is perhaps because farm size can affect and in turn be affected by the other factors that influence the adoption of innovations.

The level of disposable income of the farmers ranged between 14,376.80 and 84,031.68 with an 
Table 3: Distribution of socio-economic characteristics of homestead catfish farmers $(n=137)$

\begin{tabular}{|c|c|c|}
\hline Parameter & Frequency & Mean (Mode) \\
\hline \multicolumn{3}{|l|}{ Gender } \\
\hline Male & $86(62.8)^{*}$ & \multirow[t]{2}{*}{ (Male) } \\
\hline Female & $51(37.2)$ & \\
\hline \multicolumn{3}{|l|}{ Age } \\
\hline $26-33$ & $24(17.5)$ & \multirow{5}{*}{44} \\
\hline $34-41$ & $36(26.3)$ & \\
\hline $42-49$ & $34(24.8)$ & \\
\hline $50-57$ & $32(23.4)$ & \\
\hline $58-65$ & $11(8.0)$ & \\
\hline \multicolumn{3}{|l|}{ Marital status } \\
\hline Married & $94(68.6)$ & \multirow[t]{2}{*}{ (Married) } \\
\hline Single & $43(31.4)$ & \\
\hline \multicolumn{3}{|l|}{ Adult per household } \\
\hline $2-3$ & $107(78.1)$ & \multirow[t]{2}{*}{3 persons } \\
\hline $4-5$ & $30(21.9)$ & \\
\hline \multicolumn{3}{|l|}{ Educational status } \\
\hline No formal education (0) & $10(7.3)$ & \multirow{5}{*}{ (Secondary school) } \\
\hline Primary school (6) & $45(32.8)$ & \\
\hline Secondary school (12) & $46(33.6)$ & \\
\hline OND/NCE/HND(14-15) & $26(19.0)$ & \\
\hline University degree (16-17) & $10(7.3)$ & \\
\hline \multicolumn{3}{|l|}{ Fish farming experience (years) } \\
\hline $1-2$ & $38(27.7)$ & \multirow{5}{*}{4.3} \\
\hline $3-4$ & $44(32.1)$ & \\
\hline $5-6$ & $28(20.4)$ & \\
\hline $7-8$ & $21(15.3)$ & \\
\hline $9-10$ & $6(4.4)$ & \\
\hline \multicolumn{3}{|c|}{ Monthly Disposable income ( $* *)$} \\
\hline $14,300-31,700$ & $41(29.9)$ & \multirow{4}{*}{$43,192.89$} \\
\hline $31,800-49,200$ & $43(31.4)$ & \\
\hline $49,300-66,700$ & $35(25.6)$ & \\
\hline $66,800-84,200$ & $18(13.1)$ & \\
\hline \multicolumn{3}{|c|}{ Land area for pond construction $\left(\mathrm{m}^{2}\right)$} \\
\hline $40-70$ & $15(10.9)$ & \multirow{5}{*}{104.35} \\
\hline $71-101$ & $64(46.7)$ & \\
\hline $102-132$ & $32(23.4)$ & \\
\hline $133-163$ & $22(16.1)$ & \\
\hline $164-194$ & $4(2.9)$ & \\
\hline
\end{tabular}

${ }^{*}$ Numbers in parentheses are percentages;

${ }^{* *} 165.00=1$ US Dollar;

Source: Computed from survey data, 2016. 
average of $43,192.88$. It is farmers who can raise the capital requirement to invest in the enterprise that will participate in catfish production. According to Rogers (2003), households with a high socio-economic status and with more capital can accept the risk of adopting new technologies more easily and become innovators or early adopters.

\subsection{PROBIT MODEL RESULTS OF DETERMI- NANTS OF PARTICIPATION IN HOMESTEAD CATFISH PRODUCTION}

The results of the probit analysis of factors that affect the participation in homestead catfish production are shown in Table 4. It shows that the model has a good fit with a McFadden $R^{2}$ of $0.62,90.5 \%$ of cases correctly predicted and, a highly significant likelihood ratio (LR) test $(p<0.01)$. Therefore, all the explanatory variables together have a significant impact on the probability of a farmer participating in homestead catfish farming.

Apart from gender, marital status, farming experience and attitude to risk, all other variables had a positive and significant effect on the participation in homestead catfish farming. Age of the farmer had a positive and sig- nificant impact on the participation in catfish farming, though a negative relationship between adoption and age has been found in some studies. The findings of the study are in consonance with that of Tenge et al. (2004), who reported that elderly people are more keen to participate in new technologies because they have had more years of farming experience and more personal capital (Nkamleu and Manyong, 2005), so that they can invest in new innovations. The marginal effect revealed that an additional year in the age increases the probability of the participation in catfish production by $2.1 \%$.

Years of formal education is another variable that had a positive and significant influence on the participation decision. Operators who spent more years in school acquiring formal education are more likely to participate in catfish farming than their less educated counterparts. In fact, the results revealed that an additional year of education increases the likelihood of an individual's participation by $4.8 \%$. This result is similar to those of Nkamleu and Adesina (2000) and Adeogun et. al. (2008).

The number of adults per household, an approximation for household size, also had a direct influence on the participation. Operators from households with a large number of adults are more likely to engage in catfish farming at home than those from households with fewer

Table 4: Parameter estimates and summary statistics of the probit model for participation in homestead catfish production

\begin{tabular}{|c|c|c|c|c|c|c|}
\hline Variables & & Coefficient & Std. Error & $z$-statistic & $p$-value & $\begin{array}{l}\text { Marginal } \\
\text { effect }\end{array}$ \\
\hline Constant & & -9.0479 & 1.5812 & -5.7223 & $<0.00001$ & \\
\hline Sex & & -0.1432 & 0.3851 & -0.3717 & 0.71011 & -0.057 \\
\hline Age & & 0.0519 & 0.0191 & 2.7155 & $0.00662^{* * *}$ & 0.021 \\
\hline Marital status & & 0.5022 & 0.4111 & 1.2216 & 0.22186 & 0.196 \\
\hline Years of formal education & & 0.1270 & 0.0426 & 2.9817 & $0.00287^{* * *}$ & 0.051 \\
\hline Adult/household & & 0.4578 & 0.2067 & 2.2150 & $0.02676^{\star *}$ & 0.182 \\
\hline Fish farming experience & & 0.0787 & 0.0880 & 0.8942 & 0.37122 & 0.031 \\
\hline Disposable income & & 0.00003 & 0.00001 & 2.0959 & $0.03609^{\star *}$ & 0.00001 \\
\hline Land area & & 0.0142 & 0.0071 & 2.0033 & $0.04515^{\star *}$ & 0.006 \\
\hline Pond location & & 0.7632 & 0.3555 & 2.1469 & $0.03180^{* *}$ & 0.297 \\
\hline Attitude to risk & & -0.3653 & 0.3382 & -1.0800 & 0.28013 & -0.145 \\
\hline Credit access & & 1.2346 & 0.3631 & 3.4006 & $0.00067^{\star * *}$ & 0.455 \\
\hline Number of cases 'correctly predicted' & $=124(90.5 \%)$ & & & & & \\
\hline McFadden $R$-squared & $=0.62$ & & & & & \\
\hline Log-likelihood & $=-36.29$ & & & & & \\
\hline Likelihood ratio test: Chi-square (11) & $=117.28[0.0000]$ & & & & & \\
\hline $\begin{array}{l}\text { Null hypothesis: error is normally dist } \\
\text { Test statistic: Chi-square }(2)=18.981\end{array}$ & $\begin{array}{l}\text { ibuted } \\
\text { ith } p \text {-value }=0.00007\end{array}$ & & & & & \\
\hline
\end{tabular}

${ }^{* * *}$ significant at the $1 \%$ level; ${ }^{* *}$ significant at the $5 \%$ level; Source: Computed from survey data, 2016. 
adults. Therefore the likelihood of participation increases with the number of adults per household. Most catfish production operations require a great deal of human efforts and the availability of adults in the household of a farmer is thus an incentive for participation. The result is in agreement with those of Damisa and Yohanna (2007), Damisa et. al. (2007), and Amsalu and de Graaff (2007). The marginal effect shows that the presence of an additional adult in a household will increase the probability of participation by $18.2 \%$.

The level of monthly disposable income also exerted a positive and significant effect on the participation in homestead fish farming, because farmers with a higher income can afford the cost of the innovation and bear the associated risks (Rogers, 2003). The land area available for pond construction also had a direct effect on the participation in catfish farming because it determines the size of ponds constructed. Comparable results were reported by Zbinden and Lee (2005). The probability of participation in catfish production with respect to land area was $0.6 \%$.

The result of pond location implies that the probability of participating in homestead fish farming is higher if the pond is located in an urban or peri-urban area than in a rural area. In fact, individuals residing in urban/peri-urban centres have a $29.7 \%$ more probability of participation in catfish production than their rural counterparts.

Access to loan exerted the strongest effect on the participation decision in homestead catfish production. The result indicated that individuals who have access to loan have a greater likelihood of participation than those who cannot access loans readily. The probability of participation with respect to access to credit is $45.5 \%$. This finding is in consonance with that of Arega et al. (2008).

\section{CONCLUSION}

The present work has revealed the impact of socioeconomic variables on farmers' participation decision with respect to homestead catfish production. The majority of catfish farmers were men, with only a few women engaged in fish farming, while many of the farmers were married. Cultural factors that limit women ownership of land may have restricted their access to land for pond construction, and this may be responsible for the low level of women participation. Apart from gender, marital status, farming experience and attitude to risk, all the other variables had a positive and significant impact on the decision to participate in homestead catfish production, though the likelihood of participation was higher with respect to loan access, pond location, and adults per household. Findings of the study lend support to the advocacy for policies that will encourage investment in small-holder agriculture given the low level of fish protein consumption/capita/day (4.4 g) in Nigeria (FAO, 2014a), the growing hunger and the rising level of food insecurity in the nation. A policy to stimulate catfish production by utilising available land space in the homestead would be timely in order to boost fish protein intake and to enhance food security.

\section{REFERENCES}

Adeogun, O. A., Ajana, A. M., Ayinla, O. A., Yarhere, M. T., \& Adeogun, M. O. (2008). Application of logit model in adoption decision: a study of hybrid clarias in Lagos State, Nigeria. American-Eurasian Journal of Agriculture and Environmental Science, 4(4), 468-472.

Amsalu, A. \& de Graaff, J. (2007). Determinants of adoption and continued use of stone terraces for soil and water conservation in an Ethiopian highland watershed. Ecological Economics, 61(2-3), 294-302. https://doi.org/10.1016/j. ecolecon.2006.01.014

Arega, D. A., Manyong, V. M., Omanya, G., Mignouna, H. D., Bokanga, M. \& Odhiambo, G. (2008). Smallholder market participation under transactions costs: Maize supply and fertilizer demand in Kenya. Food Policy, 33, 318-328. https://doi.org/10.1016/j.foodpol.2007.12.001

Caswell, M. K., Fuglie, C., Ingram, S. \& Kascak, C. (2001). Adoption of Agricultural production practices: Lessons learned from the US. Department of Agriculture area studies project (Agriculture Economic Report No.792). Washington, DC: Department of Agriculture. Resource Economics Division, Economic Research service.

Chukwuji, C. O. (2010). Adoption of organic input in soil fertility management practices by smallholder farmers in Delta State of Nigeria. International Journal of Agriculture and Rural Development, 1(2), 99-107.

Damisa, M. A., Samndi, J. R., \& Yohanna, M. (2007). Women participation in agricultural production: a probit analysis. Journal of Applied sciences, 7(3), 412-414.

Damisa, M. A., \& Yohanna, M. (2007). Role of rural women in farm management decision making process: Ordered probit analysis. World Journal of Agricultural Sciences, 3(4), 543-546.

Doss, C. R. \& Morris, M. L. (2001). How does gender affect the adoption of agricultural innovation? The case of improved maize technologies in Ghana. Journal of Agricultural Economics. 25, 27-39. https://doi.org/10.1016/S01695150(00)00096-7

FAO. (2010). Fisheries and aquaculture information and statistics service, 2009. Rome: Food and Agriculture Organisation of the United Nations.

FAO. (2014a). The State of World Fisheries and Aquaculture 2014. Rome: Food and Agriculture Organisation of the United Nations.

FAO. (2014b). Yearbook of fisheries and aquaculture statistics 
2012. Rome: Food and Agriculture Organisation of the United Nations.

FAO. (2016). Yearbook of fisheries and aquaculture statistics 2014. Rome: Food and Agriculture Organisation of the United Nations.

Green, W. H. (1998). LIMDEP Version 7.0. New York: Econometric Software, Inc.

Greene, W. H. (2008). Econometric Analysis (6 $6^{\text {th }}$ edition). New Jersey: Pearson-Prentice Hall.

Gujarati, D .N. \& Porter, D. C. (2009). Basic Econometrics (5 ${ }^{\text {th }}$ edition, International Edition). New York: McGrall-Hill/ Irwin,

Inoni, O. E. (2007). Allocative efficiency in pond fish production in Delta State, Nigeria: a production function approach. Agricultura Tropica Et Subtropica, 40(4), 127-134.

Kapetsky, J. M. (1981). Some consideration for the management of coastal lagoon and estuarine fisheries (FAO Fisheries Technical Paper no. 218, pp. 42). Rome: Publications Division, Food and Agriculture Organization of the United Nations.

Nkamleu, G. B. \& Adesina, A. A. (2000). Determinants of chemical input use in peri-urban lowland systems: bivariate probit analysis in Cameroon. Agricultural Systems, 63, 111-121. https://doi.org/10.1016/S0308-521X(99)00074-8

Nkamleu, G. B. \& Manyong, V. M. (2005). Factors affecting the adoption of agroforestry practices by farmers in Cameroon. Small-scale Forest Economics, Management and Policy, 4(2), 135-148.

Olagunju, F. I., Adesiyan, I. O. \& Ezekiel, A. A. (2007). Economic viability of cat fish production in Oyo State, Nigeria.
Journal of Human Ecology, 21(2), 120-124. https://doi.org/ 10.1080/09709274.2007.11905961

Rogers, E. M. (2003). Diffusion of Innovations ( $5^{\text {th }}$ ed.). New York: Free Press.

Samiee, A., Rezvanfa, A. \& Faham, E. (2009). Factors influencing the adoption of integrated pest management (IPM) by wheat growers in Varamin County, Iran. African Journal of Agricultural Research, 4(5), 491-497.

Tenge, A. J., Graaff, J. D. \& Hella, J. P. (2004). Social and economic factors affecting the adoption of soil and water conservation in West Usambara highlands, Tanzania. Land Degradation and Development, 15(2), 99-114. https://doi. org/10.1002/ldr.606

Tobor, J. G. (1990). The fish industry in Nigeria: status and potential for self-sufficiency in fish production (NIOMR Technical Paper no. 54, pp. 34). Lagos: Nigerian Institute for Oceanography and Marine Research.

Ugwumba, C. O. A. (2005). The economics of homestead concrete fish pond in Anambra State, Nigeria. African Journal of Fisheries and Aquaculture, 4, 28-32.

Welcome, R. I. (1979). The Inland Fisheries of Africa (CIFA Occasional Paper no. 7, pp. 77). Rome: Food and Agriculture Organisation of the United Nations.

Wooldridge, J. M. (2006). Introductory Econometrics: A Modern Approach ( $3^{\text {rd }}$ edition, International Student Edition). Mason, $\mathrm{OH}$ : Thomson/South-Western.

Zbinden, S \& Lee, D. R. (2005). Paying for environmental services: an analysis of participation in Costa Rica's PSA program. World Development, 33(2), 255-272. https://doi. org/10.1016/j.worlddev.2004.07.012 